\title{
ATTITUDES OF EFL STUDENTS REGARDING LEARNER AUTONOMY IN ENGLISH VOCABULARY ACQUISITION
}

\author{
I Putu Andre Suhardiana \\ Universitas Hindu Negeri I Gusti Bagus Sugriwa Denpasar \\ putuandresuhardiana@gmail.com
}

\begin{abstract}
Practical English communication for EFL students is wholly based on their vocabulary. However, learner autonomy (LA) is critical for EFL students' vocabulary acquisition. The purpose of this research is to find out the viewpoints of students regarding LA when it comes to acquiring English vocabulary. There were 100 students from the college majoring in English Language Education Department completed the closed questionnaire, and 7 students participated in semistructured interviews. The research established that while participants intellectually recognized the relevance of LA in learning English vocabulary, they demonstrated a lack of interest in LA in learning English vocabulary on an emotional and behavioral level. These findings may help explain how to improve English teaching and learning, particularly English vocabulary teaching, in the context of other comparable EFL and research.
\end{abstract}

Keywords: Attitudes, Learner Autonomy, Vocabulary Acquisition

\section{Introduction}

Numerous researchers (e.g., Alqahtani, 2015; Alharbi, 2015, Yawiloeng, 2020) claim that vocabulary is critical for language learning since it helps learners support the four language skills. Ahmadi et al. (2012) also shown that vocabulary is critical at all stages of a learner's language development. Moreover, without the essential vocabulary, it is hard for a student to converse. Indeed, a number of researchers in the field of vocabulary (e.g., Mulder et al., 2019; Asllani \& Paçarizi, 2021; Bartolotti \& Marian, 2017) believe that communication without syntax and grammar is feasible, but not without vocabulary. Thus, it cannot be argued that without a vocabulary, learners would be unable to communicate their ideas, emotions, or feelings and will be unable to comprehend written and spoken materials. Thus, vocabulary acquisition is a critical aspect of achieving a good degree of language competency (Sa'D \& Rajabi,
2018). The concept of learner autonomy (LA) has been widely promoted as a viable alternative technique (e.g., Intraboonsom et al., 2020; Swatevacharkul \& Boonma, 2021; Lenkaitis, 2020; Basri, 2020), and has been stressed in educational settings, notably in language learning (e.g., Yasmin \& Sohail, 2018; Mario \& Chenyalin, 2019; Yasmin et al., 2020; Chiknaverova, 2018). According to Kidd et al. (2018), the ultimate goal of language acquisition is "independent learning" in all facets of language. Thus, supporting students in developing the ability to absorb vocabulary independently is a critical component of ESL/EFL teacher training in terms of vocabulary.

However, it appears that in the context of Indonesia and other EFLs, the importance of LA content in acquiring English vocabulary has been understated (e.g., Alfadil, 2020; Thompson \& von Gillern, 2020). Many EFL students 
continue to be trained passively and with a teacher-centered perspective (Caselli \& Pyers, 2020), and their present vocabulary mastery is still restricted as a result of their concentration on memorizing the lengthy lists of English vocabulary supplied by the EFL instructor (Restrepo Ramos, 2015). Besides, rather than learning the language on their own, learners are given terminology (e.g., Sok \& Han, 2020; Bisson et al., 2014). Thus, this study will examine students' opinions regarding LA when it comes to acquiring English vocabulary in a collegiate setting. The study topic is, 'How do students majoring in English education feel about using LA to acquire English vocabulary?' Scholars and academics have defined the word "LA" in a variety of ways (e.g., Kidd \& Donnelly, 2020; Kidd et al., 2018; Werker, 2018; Mohamad Nor \& Rashid, 2018). Kidd \& Donnelly (2020) describe LA as the capacity of a student to guide his or her own learning. Similarly, Çakıroğlu (2018) defines LA as "the capacity and willingness of the learner to make autonomous choices." Furthermore, Hartshorne et al. (2018) defined LA as "the capacity to appraise one's own learning responsibility." In a similar vein, Werker (2018) defines LA as "the capacity to manage learning and content," and other researchers (e.g., Höhle et al., 2020; Çakıroğlu, 2018; Brandt et al., 2012; Broad \& Columbia, 2020) have demonstrated that LA is a complex process in which learners must develop into more active and autonomous agents both inside and outside the classroom. In summary, learner autonomy is defined in a variety of ways. LA is defined in this study as a learner's desire and capacity to take responsibility for their own learning.
Vocabulary acquisition is a substantial obstacle for language learners (Höhle et al., 2020), as without the essential vocabulary items, learners cannot communicate. However, because a learner cannot learn all of the vocabularies in a single language session, he or she must discover additional effective methods for acquiring the language's vocabulary. LA is a powerful tool for vocabulary acquisition since it delivers several benefits to students (Gan et al., 2018). Not only can LA improve learners' motivation to acquire vocabulary more successfully, but it also provides more possibilities for language conversation. Moreover, it takes into account the learners' unique requirements and talents. Besides, it enhances learners' preparedness for active learning and aids in their confidence development. On the other hand, Nada (2015) asserts that LA is extremely beneficial for the following two reasons. The first reason is that LA aids in the development of learners' learning. The second purpose is to assist learners in developing an engaging motivation to study. As a result, the significance of LA in the language acquisition process cannot be overstated. Throughout the process, the attitude was a critical component in helping to construct LA. According to van den Berg \& Klapwijk (2020), a positive attitude is a critical element in the development of LA.

Attitudes are defined as "psychological inclinations reflected in the degree to which one likes or dislikes a specific thing" (Shirbagi, 2010), and they are composed of three components: cognitive, emotional, and behavioral (Culhane, 2004). Cakir (2020) asserts that students' attitudes have a major impact on 
their behavior and performance. Attitudes can have an impact on how learners think, feel, and act. In other words, attitudes are believed to have a significant effect on all decisions and acts (e.g., Shirbagi, 2010; Zainal Abidin \& Lock Kim Wai, 2020; Zulkefly \& Razali, 2019; Mahdikhani, 2016). Wesely (2012) argues that 'attitudes and beliefs are components of the construct that defines, describes, and explains the forms and content of mental states thought to influence a person's behavior'. Moreover, Kidd \& Donnelly (2020) indicates that language acquisition success is influenced by not just intellectual capacity but also attitude. On a more academic level, Zulkefly \& Razali (2019) observes that student attitudes have been identified as a significant predictor of learning results. There are two sorts of attitudes: positive and negative. A student who is passionate about the target language will work hard in class and study diligently. On the other side, a pessimistic mindset might undermine language learning's continuation.

The previous study has demonstrated that research has been conducted in a variety of areas of LA in English acquisition. Numerous studies have studied attitudes about LA in the context of English acquisition (e.g., Jacoby \& Lesaux, 2019; Al Zoubi, 2018; Al-Nasser, 2015; Mustafa et al., 2019). Jacoby \& Lesaux (2019) did an intriguing study on knowledge acquisition and advancement by demonstrating that this assumption applies to Head Start instructors dealing with an increasing number of youngsters learning several languages. Twenty Head Start instructors teaching classes with a majority of Latino DLL children participated in this qualitative study through interviews that featured practicebased vignettes for participants to assess and respond. Teachers say that they feel it is critical to building social-emotional skills in DLL children, adding that these abilities serve as the foundation for supporting DLL children's English proficiency. Moreover, the participating instructors stated that they thought that including Spanish in the classroom will aid in the development of socialemotional skills in DLL children, therefore facilitating their eventual acquisition of English. Finally, the interviews indicated that the participating instructors thought that in a preschool environment, English proficiency comes spontaneously and effortlessly.

Researchers have investigated strategies for language learners in general and vocabulary learning in specific in the Indonesian language context (e.g., Lestari \& Hardiyanti, 2020; Nurapriani et al., 2019; Cahyono \& Widiati, 2015). Lestari \& Hardiyanti (2020) performed a qualitative study in which they examined the experiences of Indonesian students who used English songs as a medium for independently acquiring vocabulary outside of the classroom. The data were gathered through in-depth interviews with four second-year English Department students who stated that they used English songs to assist them in independently acquiring vocabulary. The interview revealed that participants preferred songs with slow beat tempos in order to obtain a good comprehension of the lyrics. Moreover, they reported that their choice of English songs was motivated by their desire for authentic and contextual exposure to the English lexicon, representation of learners' feelings 
and emotions through songs, a sense of the pleasant atmosphere created by the song, and retention of vocabulary. While listening to English music, participants used cognitive and metacognitive techniques to aid in the successful acquisition of vocabulary. Finally, this research proposes the role of instructors in increasing student autonomy when it comes to vocabulary acquisition through English songs. Cahyono \& Widiati (2015) discuss different aspects of teaching EFL vocabulary and link them to the broader context of teaching second/foreign language vocabulary. They also evaluate current research findings and practice in the Indonesian setting for teaching and learning EFL vocabulary.

\section{Method}

\subsection{Research Location and Participants}

This mixed-methods study is conducted in an academic context. The research enrolled 100 first- and secondyear English majors who were randomly chosen to complete the questionnaire. There are 42 male students and 58 female students, as indicated in Table 1. Over half of students $(72 \%)$ spent less than an hour per day learning English vocabulary, while a minority $(4 \%)$ spent more than two hours each day. Further, 16\% spent an hour, and 8 percent spent one to two hours. Ten students were chosen at random from 100 individuals to participate in a semi-structured interview. They are chosen based on their volunteerism and the number of hours they devote to language study each day.

Table 1. General Information on the Participants in the Research

\begin{tabular}{|l|l|c|c|c|}
\hline No. & \multicolumn{2}{|c|}{ Information } & \multicolumn{2}{c|}{$\mathrm{N}=100$} \\
\hline & \multicolumn{2}{|c|}{} & $\mathrm{F}$ & $\%$ \\
\hline 1. & Gender & Male Students & 42 & 42 \\
\cline { 3 - 5 } & & Female Students & 58 & 58 \\
\hline 2. & Daily hours spent studying English vocabulary & Less than 1 hour & 72 & 72 \\
\cline { 3 - 6 } & & About 1 hour & 16 & 16 \\
\cline { 3 - 6 } & & $1-2$ hours & 8 & 8 \\
\cline { 3 - 6 } & & More than 2 hours & 4 & 4 \\
\hline
\end{tabular}

\subsection{Research Instruments}

Specifically, two research tools for data gathering: closed questionnaires and semi-structured interviews were employed. The questionnaire is divided into two sections: Part A collects demographic information about respondents; Part B (primary content) elicits information on the respondent's attitude regarding using LA to acquire English vocabulary. The primary content consists of twelve closed items on a fivepoint Likert scale (from strongly disagree to strongly agree). The first eight items address the essential nature of autonomous English vocabulary acquisition (the cognitive component), whereas the ninth through twelve items address the desire to acquire autonomous English vocabulary (affective \& behavioral components). The questionnaire was translated into Indonesian to guarantee that respondents could reply without encountering linguistic obstacles. All surveys had a Cronbach's alpha value of 0.79 , suggesting that they were extremely 
trustworthy. Three key questions were included in the semi-structured interview in order to elicit specific information regarding participants' perspectives toward LA in the context of English vocabulary learning. Interviews were held in Indonesian to ensure that students could express their thoughts and emotions entirely.

\subsection{Procedures for Data Collection and} Analysis

In terms of data collecting, they were used following a trial of the official questionnaire and interview technique. Directly delivered questionnaires and instructions were followed. The questionnaire took respondents roughly 15 minutes to complete. Following that, the questionnaire was returned. Then, 7 students were asked to participate in a semi-structured face-to-face interview. Interviews were placed during and after class. The interviewees were briefed on the interview process. Each interview lasted between twenty and twenty-five minutes. All interviews were taped in order to do additional analysis. In terms of data analysis, SPSS was used to examine quantitative data from surveys using descriptive statistics, whilst content analysis was used to analyze qualitative data from interviews. To ensure the qualitative data analysis's validity and reliability, two academics specializing in English studies were requested to reanalyze three randomly selected portions of the data. At least 96 percent of results must coincide among investigators.

\section{Finding and Discussion}

\subsection{Finding}

1) Attitudes of English Language Education Department students about the use of LA in English vocabulary instruction

As indicated in Table 2, the average score for students majoring in English education as a whole in terms of their attitude toward LA in acquiring English vocabulary was 3.305 (out of 5). The mean score for the significance of independent English vocabulary mastery was relatively high (Group 1: $M=4.16$, SD $=0.74)$; nevertheless, the mean score for personal interest in English vocabulary acquisition was fairly low (Group 2: $\mathrm{M}=$ $2.45, \mathrm{SD}=0.71$ ). Individuals are cognizant of the necessity of autonomously acquiring English vocabulary at the cognitive level, but are disinterested and disconnected at the affective and behavioral levels.

Table2. Attitudes of English Language Education Department Towards LA in English Vocabulary Learning

\begin{tabular}{|l|c|c|c|}
\hline & $\mathrm{N}$ & Mean & Std. Deviation \\
\hline Component of cognitive & 100 & 4.1600 & .74833 \\
Components of cognitive & 100 & 2.4500 & .71598 \\
Valid N (listwise) & 100 & 3.305 & .73215 \\
\hline
\end{tabular}


2) Attitudes of English Language Education Department Students Towards LA in English Vocabulary Learning in Terms of the Cognitive Component

Table 3 demonstrates the crucial importance of individual English vocabulary mastery. Cognitively, participants unanimously agreed that "English language learning requires autonomous vocabulary acquisition" (No. 2: $\mathrm{M}=4.65, \mathrm{SD}=0.55$ ) and "Autonomous English vocabulary acquisition is critical for English language learning" (No. 1: $\mathrm{M}=4.59, \mathrm{SD}=.57$ ). Besides, they believe that autonomous English vocabulary acquisition aids in their improvement of their speaking ability (No. 4: $\mathrm{M}=4.10$, SD
=.73), autonomous English vocabulary acquisition aids in the development of their listening ability (No. 5: $\mathrm{M}=4.07$, SD $=.72$ ), autonomous English vocabulary acquisition assists them in improving their reading ability (No. 6: $\mathrm{M}=4.56, \mathrm{SD}=0.64$ ), autonomous English vocabulary acquisition assists them in improving their writing ability (No. 7: $\mathrm{M}=4.45, \mathrm{SD}=0.64$ ), and autonomous English vocabulary acquisition aids in their comprehension of English grammar (No. 8: $\mathrm{M}=4.08, \mathrm{SD}=$ 0.73). Participants, on the other hand, thought that independent English vocabulary mastering "aided in strengthening their English abilities" (No. 3: $\mathrm{M}=4.06, \mathrm{SD}=.72$ ).

Table 3. Attitudes of English Language Education Department Students Towards Language Acquisition in English Vocabulary Learning (Cognitive Component)

\begin{tabular}{|c|c|c|c|}
\hline & $\mathrm{N}$ & Mean & Std. Deviation \\
\hline $\begin{array}{l}\text { Autonomous English vocabulary acquisition is critical for English } \\
\text { language learning }\end{array}$ & 100 & 4.5900 & .57022 \\
\hline $\begin{array}{l}\text { English language learning requires autonomous vocabulary } \\
\text { acquisition }\end{array}$ & 100 & 4.6500 & .55732 \\
\hline $\begin{array}{l}\text { Autonomous English vocabulary acquisition aids in my language } \\
\text { competence development }\end{array}$ & 100 & 4.0600 & .72223 \\
\hline $\begin{array}{l}\text { Autonomous English vocabulary acquisition aids in the } \\
\text { improvement of my speaking ability }\end{array}$ & 100 & 4.1000 & .73168 \\
\hline $\begin{array}{l}\text { Autonomous English vocabulary acquisition aids in the } \\
\text { development of my listening ability }\end{array}$ & 100 & 4.0700 & .72829 \\
\hline $\begin{array}{l}\text { Autonomous English vocabulary acquisition assists me in } \\
\text { improving my reading ability }\end{array}$ & 100 & 4.5600 & .64071 \\
\hline $\begin{array}{l}\text { Autonomous English vocabulary acquisition assists me in } \\
\text { improving my writing ability }\end{array}$ & 100 & 4.4500 & .64157 \\
\hline $\begin{array}{l}\text { Autonomous English vocabulary acquisition aids in my } \\
\text { comprehension of English grammar }\end{array}$ & 100 & 4.0800 & .73416 \\
\hline Valid N (listwise) & 100 & & \\
\hline
\end{tabular}

Qualitative analysis found consistent tendencies with the respondent's questionnaire, stressing the necessity of autonomy in the growth of English vocabulary. They share the following characteristics:
I believe that studying English vocabulary individually is critical because it enables me to more thoroughly comprehend the new terms I am learning in class and, from there, to better comprehend and retain 
information from prior courses and vocabulary (A1).

I feel that LA is critical and required for the learning of other English skills. While I recognized that the assistance of English lecturers and classmates was really beneficial, they were not always available (A2).

For me, gaining English vocabulary independently is critical because I feel that the more vocabulary I acquire on my own, the better my English will be (A3).
3) The Affective and Behavioral Components of English Language Education Department Students' Attitudes

As illustrated in Table 4, participants' emotional attitudes about "I find it fascinating to study English vocabulary independently" (No. 1: $\mathrm{M}=$ $2.88, \mathrm{SD}=0.68$ ) and " I like learning English language on my own" (No. 2: M = $2.94, \mathrm{SD}=0.72$ ) are unclear. Concerning the behavioral component, the students did not "establish objectives for selfdirected English vocabulary acquisition" (No. 3: $\mathrm{M}=2.56, \mathrm{SD}=0.60$ ) or "frequently review vocabulary before class" (No. 4: M $=2.37, \mathrm{SD}=0.59)$. Additionally, the standard deviation for items 1, 2, 3, and 4 was quite large, indicating that the participant's responses to these questions were quite dispersed.

Table 4. The Affective and Behavioral Components of English Language Education Department Students' Attitudes

\begin{tabular}{|l|c|c|c|}
\hline & N & Mean & Std. Deviation \\
\hline I find it fascinating to study English vocabulary independently. & 100 & 2.8800 & .68579 \\
I like learning the English language on my own. & 100 & 2.9400 & .72223 \\
I establish objectives for self-directed English vocabulary & 100 & 2.5600 & .60836 \\
acquisition. & 100 & 2.3700 & .59722 \\
Ifrequently review vocabulary before class. & 100 & & \\
Valid N(listwise) & & \\
\hline
\end{tabular}

The findings from the semistructured interviews confirmed some of the questionnaire's conclusions. For instance, several students stated that: "It's really tough for me to pick up terminology on my own after class." Although most of them are urged by their lecturers to acquire vocabulary individually, we are unsure how to do so. As a result, I generally save time for vocabulary study immediately before a test or exam (A4).
I confess that I am uninterested in expanding my vocabulary. I understand why it is critical, but studying language is really dull for me (A5). I despise studying vocabulary because I lack the knowledge necessary to do it properly and fast. Without the assistance and direction of my English instructor, I find it impossible to acquire vocabulary alone after class. Besides, the interview findings revealed a lack of explicit purpose planning for vocabulary development. For instance, I 
make no attempt to increase my vocabulary. I simply wish to pass the examination, and I am not a native English speaker (A6). To be honest, I rarely set a specific goal for my new words acquisition. I'm required to study for another class (after class) and complete a substantial amount of assignments. As a result, I frequently dedicate my free time to studying it when lecturers ask questions or when an English exam approaches (A7).

\subsection{Discussion}

Numerous key topics are addressed in this research. The majority of participants had good attitudes toward LA in the context of English learning. This finding is consistent with earlier studies (e.g., Gan et al., 2018; AlMansour, 2016; Shirbagi, 2010), which indicated that students generally had good attitudes of LA and, in particular, when it came to acquiring English vocabulary. This is viewed as a positive condition that might help lecturers increase their efforts and confidence while teaching language to their students. In other words, the favorable attitude of English majors about independently acquiring English vocabulary may be viewed as a great motivator for students to devote significant time to vocabulary learning. Cognitively, participants thought that LA was critical to their English proficiency. This research demonstrates that EFL secondary school students are willing to take ownership of their vocabulary acquisition. This conclusion is reinforced by Haddad's (2016) findings, which indicated that respondents demonstrated an eagerness and capacity for self-directed learning. By contrast, Wiraningsih \&
Santosa (2020) discovered that students of English as a foreign language had a relatively low understanding of learner autonomy and readiness to develop into self-sufficient learners. One possible explanation is that the participants are English majors who have spent several years studying the language. As a result, they are fully aware of the need to increase their English vocabulary and the function of language acquisition in doing so.

The respondents, on the other hand, exhibited neutral emotional attitudes about LA in terms of acquiring English vocabulary and negative attitudes toward LA. Furthermore, because the standard deviation values do not converge, many participants may have positive affective views. This conclusion contradicts their cognitive stance regarding LA when it comes to vocabulary acquisition in English. It is understandable that, while participants thought that using LA to acquire English vocabulary was critical and beneficial for improving their English, they seemed somewhat hesitant to do so. Numerous interpretations exist for the findings. The explanation might be that many people find it tedious to study English vocabulary on their own, and so rely on their lecturers to provide new terms throughout each class. The second reason might be that the participants are first- and second-year students who are unfamiliar with effective vocabulary acquisition techniques. The second explanation might be that the participants lacked independence in their learning, since almost $70 \%$ of participants reported allocating less than an hour each day to acquiring English vocabulary. This study corroborates Caselli \& Pyers's (2020) 
results that, while students are ready to take ownership of their language development, They prefer to submit to the lecturers' authority and control throughout the learning process. Intraboonsom et al. (2020) discovered that when students practice with suitable language learning strategies, they may gradually improve their autonomy by independently selecting and using numerous words in a variety of circumstances. This might imply a mismatch between participants' understanding of LA English vocabulary acquisition and their emotions and conduct during autonomous English vocabulary acquisition. The outcome appears to be consistent with Haddad's (2016) findings that students understand the importance of autonomy in vocabulary mastering yet have a neutral incentive for extending their English vocabulary knowledge.

\section{Conclusion}

Numerous inferences are possible from this study. Although participants believed that LA was critical in learning English and developing their English abilities, some individuals supported LA in the acquisition of affective and behavioral English vocabulary. There is a disconnect between participants' cognitive attitudes regarding LA and their emotional attitudes and conduct toward LA when it comes to acquiring English vocabulary. This discovery has a lot of ramifications. While students are aware of the critical function of LA in English vocabulary learning, their engagement in English vocabulary acquisition (affective attitudes and actions) is low. As a result, lecturers must excite learners and illustrate how to study the language independently through the use of English music and subtitled films. Besides, students should be taught to plan, establish objectives, monitor, and evaluate their own development of English vocabulary. Moreover, lecturers should be proactive in monitoring and analyzing students' English language learning processes in general, and their acquisition of English vocabulary in particular. Numerous constraints apply to these small-scale studies. First, this study was confined to a single aspect of LA in the context of English language learning. Second, this study enrolled only first- and second-year undergraduate students. As a result, it is recommended that future research include a broad sample of students in order to generalize the findings to a larger population.

\section{References:}

Ahmadi, M. R., Ismail, H. N., \& Abdullah, M. K. K. (2012). Improving Vocabulary Learning in Foreign Language Learning Through Reciprocal Teaching Strategy. International Journal of Learning and Development, 2(6). https://doi.org/10.5296/ijld.v2i6.2 882

Al-Nasser, A. S. (2015). Problems of English Language Acquisition in Saudi Arabia: An Exploratorycum-remedial Study. Theory and Practice in Language Studies, 5(8). https://doi.org/10.17507/tpls.0508 .10

Al Zoubi, S. (2018). The Impact of Exposure to English Language on Language Acquisition. Journal of Applied Linguistics and 
Language Research, 5(4).

Alfadil, M. (2020). Effectiveness of virtual reality game in foreign language vocabulary acquisition. Computers and Education, 153. https://doi.org/10.1016/j.comped u.2020.103893

Alharbi, A. M. (2015). Building vocabulary for language learning: Approach for ESL learners to study new vocabulary. In Journal of International Students (Vol. 5, Issue https://doi.org/10.32674/jis.v5i4.4 11

AlMansour, N. (2016). Effect of Attitude on Foreign Language Acquisition: Arabic Pronunciation as Case Study. Arab World English Journal, 7(1). https://doi.org/10.24093/awej/vol 7no1.18

ALQAHTANI, M. (2015). The importance of vocabulary in language learning and how to be taught. International Journal of Teaching and Education, III(3). https://doi.org/10.20472/te.2015.3 .3 .002

Asllani, H., \& Paçarizi, R. (2021). Enhancing second language incidental vocabulary learning through technology. In Journal of Educational and Social Research (Vol. 11, Issue 4). https://doi.org/10.36941/jesr2021-0081

Bartolotti, J., \& Marian, V. (2017). Bilinguals' Existing Languages Benefit Vocabulary Learning in a Third Language. Language Learning, $\quad 67(1)$. 
Educational Technology, 6(3). https://doi.org/10.30935/cedtech/ 6152

Çakıroğlu, A. (2018). The language acquisition approaches and the development of literacy skills in children. International Electronic Journal of Elementary Education, 11(2).

https://doi.org/10.26822/iejee.201 9248600

Caselli, N. K., \& Pyers, J. E. (2020). Degree and not type of iconicity affects sign language vocabulary acquisition. Journal of Experimental Psychology: Learning Memory and Cognition, 46(1). https://doi.org/10.1037/xlm00007 13

Chiknaverova, K. (2018). Fostering foreign-language teaching at university by developing students' autonomy: The exploratory experiment. Global Journal of Foreign Language Teaching, $7(4)$. https://doi.org/10.18844/gjflt.v7i4 .3002

Culhane, S. F. (2004). An Intercultural Interaction Model: Acculturation Attitudes in Second Language Acquisition. Electronic Journal of Foreign Language Teaching, 1(1).

Gan, Y., Sude, Xie, J., Cheng, L., Tan, Y., \& Zhang, F. (2018). The impact of students' personal characteristics on tibetan language attitude and acquisition: A survey of the ganzi tibetan autonomous prefecture in Sichuan Province, China. NeuroQuantology, 16(5). https://doi.org/10.14704/nq.2018.
16.5.1241

Haddad, R. H. (2016). Developing Learner Autonomy in Vocabulary Learning in Classroom: How and Why can it be Fostered? Procedia - Social and Behavioral Sciences, 232. https://doi.org/10.1016/j.sbspro.2 016.10.106

Hartshorne, J. K., Tenenbaum, J. B., \& Pinker, S. (2018). A critical period for second language acquisition: Evidence from 2/3 million English speakers. Cognition, 177. https://doi.org/10.1016/j.cognitio n.2018.04.007

Höhle, B., Bijeljac-Babic, R., \& Nazzi, T. (2020). Variability and stability in early language acquisition: Comparing monolingual and bilingual infants' speech perception and word recognition. In Bilingualism (Vol. 23, Issue 1). https://doi.org/10.1017/S13667289 19000348

Intraboonsom, C., Darasawang, P., \& Reinders, H. (2020). Teacher's practices in fostering learner autonomy in a thai university context. Journal of Language Teaching and Research, 11(2). https://doi.org/10.17507/jltr.1102. 07

Jacoby, J. W., \& Lesaux, N. K. (2019). Supporting dual language learners in Head Start: teacher beliefs about teaching priorities and strategies to facilitate English language acquisition. Journal of Early Childhood Teacher Education, 40(2). 
https://doi.org/10.1080/10901027.

2018.1529006

Kidd, E., \& Donnelly, S. (2020). Individual Differences in First Language Acquisition. In Annual Review of Linguistics (Vol. 6). https://doi.org/10.1146/annurevlinguistics-011619-030326

Kidd, E., Donnelly, S., \& Christiansen, M. H. (2018). Individual Differences in Language Acquisition and Processing. In Trends in Cognitive Sciences (Vol. 22, Issue 2). https://doi.org/10.1016/j.tics.2017. 11.006

Lenkaitis, C. A. (2020). Technology as a mediating tool: videoconferencing, L2 learning, and learner autonomy. Computer Assisted Language Learning, 33(56).

https://doi.org/10.1080/09588221. 2019.1572018

Lestari, I. W., \& Hardiyanti, N. (2020). Vocabulary learning autonomy through incorporation of english songs: Indonesian EFL students' perspectives. $3 \mathrm{~L}$ : Language, Linguistics, Literature, 26(2).

https://doi.org/10.17576/3L-20202602-07

Mahdikhani, Z. (2016). An Overview of Motivation: The Challenges and the Importance of Motivation for Second Language Acquisition. Journal for the Study of English Linguistics, 4(1). https://doi.org/10.5296/jsel.v4i1.9 407

Mario, V., \& Chenyalin. (2019). Technology as enabler of learner autonomy and authentic learning in chinese language acquisition: A case study in higher education. Journal of Technology and Chinese Language Teaching, 10(2).

Mohamad Nor, N., \& Rashid, R. A. (2018). A review of theoretical perspectives on language learning and acquisition. In Kasetsart Journal of Social Sciences (Vol. 39, Issue 1). https://doi.org/10.1016/j.kjss.2017 .12 .012

Mulder, E., Van De Ven, M., Segers, E., \& Verhoeven, L. (2019). Context, word, and student predictors in second language vocabulary learning. Applied Psycholinguistics, $\quad 40(1)$. https://doi.org/10.1017/S01427164 18000504

Mustafa, M. C., Radzi, N. M. M., Masnan, A. H., Bacotang, J., Isa, Z. M., Osman, Z., \& Alias, A. (2019). Teacher practices in the acquisition of English among Asian immigrant english language learners. Malaysian Journal of Learning and Instruction, 16(1).

https://doi.org/10.32890/mjli2019. 16.1.9

Nurapriani, R., Yanuarsari, R., Ruswandi, A., Muchtar, H., \& Hakim, L. (2019). Indonesian Vocabulary Learning for Early Childhood Using Paper Puppet Media.

https://doi.org/10.4108/eai.19-102018.2281317

Restrepo Ramos, F. D. (2015). Incidental Vocabulary Learning 
in Second Language Acquisition:

A Literature Review. PROFILE Issues in Teachers' Professional Development, 17(1). https://doi.org/10.15446/profile.v 17n1.43957

Sa'D, S. H. T., \& Rajabi, F. (2018). Teaching and learning vocabulary: What English language learners perceive to be effective and ineffective strategies. Center for Educational Policy Studies Journal, 8(1). https://doi.org/10.26529/cepsj.492 Shirbagi, N. (2010). An Exploration of Undergraduate Students' Motivation and Attitudes towards English Language Acquisition. Journal of Behavioural Sciences, 20(2).

Sok, S., \& Han, Z. H. (2020). A study of L2 vocabulary acquisition under incidental and intentional conditions. Vigo International Journal of Applied Linguistics, 17. https://doi.org/10.35869/VIAL.V0 I17.1467

Swatevacharkul, R., \& Boonma, N. (2021). Learner autonomy assessment of English language teaching students in an international program in Thailand. Indonesian Journal of Applied Linguistics, 10(3). https://doi.org/10.17509/ijal.v10i3 .31764

Thompson, C. G., \& von Gillern, S. (2020). Video-game based instruction for vocabulary acquisition with English language learners: A Bayesian meta-analysis. Educational Research Review, 30. https://doi.org/10.1016/j.edurev.2 020.100332

van den Berg, L., \& Klapwijk, N. (2020). The Impact of SecondLanguage Storybook Reading on the Vocabulary Acquisition of Grade 1 Learners. Language Matters, $\quad 51(1)$. https://doi.org/10.1080/10228195. 2019.1657488

Werker, J. F. (2018). Perceptual beginnings to language acquisition. In Applied Psycholinguistics (Vol. 39, Issue 4).

https://doi.org/10.1017/S01427164 18000152

Wesely, P. M. (2012). Learner Attitudes, Perceptions, and Beliefs in Language Learning. In Foreign Language Annals (Vol. 45, Issue SUPPL.1). https://doi.org/10.1111/j.19449720.2012.01181.x

Wiraningsih, P., \& Santosa, M. H. (2020). EFL teachers' challenges in promoting learner autonomy in the 21st-century learning. Journal on English as a Foreign Language.

https://doi.org/10.23971/jefl.v10i2 .1881

Yasmin, M., Naseem, F., \& Abas, N. (2020). Constraints to developing learner autonomy in Pakistan: university lecturers' perspectives. Educational Research for Policy and Practice, 19(2). https://doi.org/10.1007/s10671019-09252-7

Yasmin, M., \& Sohail, A. (2018). A creative alliance between learner autonomy and English language 
learning: Pakistani university teachers' beliefs. Creativity Studies, $11(1)$. https://doi.org/10.3846/23450479. 2017.1406874

Yawiloeng, R. (2020). Second Language Vocabulary Learning from Viewing Video in an EFL Classroom. English Language Teaching, 13(7). https://doi.org/10.5539/elt.v13n7 p76

Zainal Abidin, H., \& Lock Kim Wai, T. (2020). Learning Poetry: Attitudes and Challenges Faced by ESL Students. LSP International Journal, 7(2). https://doi.org/10.11113/lspi.v7.1 6343

Zulkefly, F., \& Razali, A. B. (2019). Malaysian rural secondary school students' attitudes towards learning English as a second language. International Journal of Instruction, 12(1). https://doi.org/10.29333/iji.2019.1 $2173 a$ 